\title{
Teaching Microcomputer Literacy: New Roles for Academic Librarians
}

\author{
Linda J. Piele, Judith Pryor, \\ and Harold W. Tuckett
}

\begin{abstract}
While microcomputer labs and software collections are increasingly a part of college and university libraries, most librarians are not instructing users in microcomputer literacy, despite the clear need of many users for such instruction. In many cases, librarians do not believe that it is their role to provide such instruction. This paper will contend that it is indeed their role and that if one views microcomputers as important tools for information retrieval and management, librarians' role in teaching users about them is vital. By examining the experience of one academic library in assuming a central role in the administration of a microcomputer lab and in campuswide microcomputer literacy instruction, changes in librarians' professional roles are suggested, and the implications of such a role are examined.
\end{abstract}

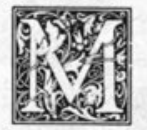

icrocomputer labs and software collections for the use of patrons have become a feature of many college and university libraries over the past few years. In 1981, libraries adding such services were rare enough to be reported individually in the library press. By 1984, according to a survey reported in Library Journal, 45.7 percent of the college and university libraries responding made microcomputers available to the public and 43.4 percent did so with software. ${ }^{1}$ And in a survey of ARL libraries taken in January 1984, twenty-four of eighty-five respondents reported having microcomputer facilities for users. ${ }^{2}$

Colleges and universities looking for locations for microcomputer labs have tended to view any library with available space as a suitable location largely due to such factors as central location, long hours, ability to provide access and con- trol for software, and service orientation. Libraries, for their part, have had a wide range of responses to this institutional need, sometimes resisting, but more often accepting, welcoming, or actively seeking responsibility for these additional services. For most, the primary rationale for doing so was probably to support the curriculum and research by providing access to instructional and application software. But libraries have had other purposes, too, including collection of data available on floppy disk (and now CD/ROM), development of end-user online search services, and support for general computer literacy, continuing education, and faculty development. ${ }^{3}$ Additionally, a few libraries have had special library educational missions in mind, such as the use of computer-assisted-instruction software for library instruction. Few, however, have considered the specialized teaching

Linda J. Piele is head of the Public Services Division, Judith Pryor is coordinator of instruction, and Harold W. Tuckett is coordinator of database searching at the Library/Learning Center, University of Wisconsin-Parkside, Kenosha, WI 53141. This paper was presented at the ACRL Fourth National Conference in Baltimore, April 9-13, 1986. 
skills of instruction librarians and the implications of these skills for microcomputer labs. (A notable exception is the Mann Library Microcomputer Center at Cornell University. $)^{4}$

A major problem faced by libraries adding microcomputers is the necessity of coping with the lack on the part of many users of microcomputer training and their overwhelming need for assistance. Methods adopted to deal with this problem range from posting signs advising patrons to go to the computer center for assistance to hiring and training student assistants to staff the area. But many patrons are not comfortable learning on their own; some don't realize-even in 1986-that they don't need to know how to program to use a microcomputer; even if assistance is available, many are reluctant or uncomfortable in seeking it out. Thus, there is a strong need for various types of group training and instruction.

Even with this obvious need on the part of users, however, academic librariansincluding instruction librarians-are not generally providing such instruction. Possible reasons for this situation include (in addition to a shortage of staff time) a lack of clarity on many campuses as to the unit responsible for providing such assistance, lack of microcomputer skills and/or confidence on the part of librarians, and the fact that many librarians simply don't think it is their role to teach microcomputer skills-it sounds too much like teaching computer science.

This paper will take exception to these assumptions, particularly the last one. It will be argued that the microcomputerfar from being seen as a programmer's instrument-should be seen, at least as far as the needs of many faculty, staff, and students are concerned, as an information retrieval and management tool, and, as such, something with which librarians, as information professionals, should be vitally involved. Furthermore, the implications of this point of view and of developments in technology and telecommunications will have profound implications for the professional roles of academic librarians in the future. By examining the experience of one academic library in assuming a central role in the administration of a microcomputer lab and, more importantly, in campuswide microcomputer literacy instruction, one such appropriate role will be suggested and the implications of such a professional role examined.

In the fall of 1982, a microcomputer lab was made available to the users of the Library/Learning Center at the University of Wisconsin-Parkside. The university administration chose this unit as the most suitable to house and administer a campus microcomputer facility because of its service orientation and open and nonintimidating atmosphere. ${ }^{5}$ Although it has grown considerably since that time, this site remains the sole microcomputer facility for this campus of approximately five thousand students. At the time it opened, two of the major goals of the lab were to support the curriculum and to provide a facility to promote general computer literacy for the entire campus community. For the reasons cited above, librarians soon realized that there was a strong need to offer general microcomputer instruction.

To respond to these needs, two librarians from the public services staff began regularly offering a hands-on general orientation workshop to introduce students, faculty, and staff to the use of microcomputers. After the need for follow-up workshops on several specific applicationsword processing, file management, and electronic spreadsheets-became apparent, workshops on each of these applications were developed and taught the following semester. All workshops were two hours in length and taught in two-person teams, with librarians serving alternately as "presenter" and "troubleshooter."

After approximately one year, the seven reference/instruction librarians in the public services division reached the collective decision that they should all participate in this program of microcomputer instruction. All librarians had attended in-house hands-on workshops similar to the orientation workshops, and many had trained themselves further in the use of microcomputers by learning to use a particular application program to accomplish a library or professional task. The team teaching method allowed those who had 
not yet taught workshops to work initially with one of the more experienced workshop leaders. Although most librarians found that teaching the workshops initially required extensive preparation and was stressful, all were reasonably comfortable in this role within a few months. Further, most found the experience to be stimulating professionally and the enthusiasm of workshop participants gratifying. As a result of the participation of a total of seven librarians as instructors, the library was able to offer a workshop approximately every two weeks without creating an unreasonable work load for any staff member and to expand its workshop offerings to include one on the use of bibliography management software.

During this period, as librarians increased their level of computer literacy and awareness, they became aware that the objectives of the microcomputer instruction program should be expanded. The potential applications of microcomputers to library research tasks became more apparent with new information becoming available-in some cases exclusively-in machine-readable format, whether on floppy or optical disks or via telecommunications. An online catalog was also in the foreseeable future. Librarians became convinced that instruction in information literacy-the skills and knowledge necessary to find and utilize needed information, regardless of its physical location or format ${ }^{6}$ - was an important goal of the bibliographic instruction program and that microcomputer literacy was an important subgoal.

Librarians therefore developed a series of seminars directed at faculty on the use of microcomputers as a tool to enhance library-related research and teaching tasks. Included in the series were presentations on end-user searching, management of bibliographies and research notes, and presentation graphics. Unlike the workshop series, these seminars are more conceptual in nature. Relevant software is demonstrated, but little hands-on experience is offered. Plans call for inviting faculty and staff members from other campus units who have specialized microcomputer expertise to participate as in- structors in future seminars. Librarians also experimented on a trial basis with incorporating instruction on these topics into the ongoing bibliographic instruction program.

The workshops and seminars have been both well attended and well received; formal evaluations, informal feedback, and librarians' perceptions have all been generally very positive. In terms of the specifics of designing and offering workshops, the hands-on instruction method turns out to be effective, particularly for novice computer users, who have one overriding need: to use a microcomputer successfully. The hands-on approach meets this need by minimizing theory and emphasizing a learning-by-doing approach. Assigning two participants to each microcomputer works well for orientation instruction; not only do they get sufficient hands-on experience, but they are often able to assist each other, reducing both their anxiety and the amount of classroom time that must be devoted to troubleshooting.

Hands-on workshops are, however, time-consuming for both students and instructors. Teams of at least two persons are essential for teaching introductory hands-on workshops of more than five participants. Trained microcomputer student assistants serving as troubleshooters can be used effectively in many cases as the second member of the team. The timeconsuming nature of hands-on microcomputer instruction will require that strategies and methods for integrating it into the existing bibliographic instruction curriculum be carefully developed. Although researchers using a library can profit from use of a number of microcomputer applications, it takes a considerable amount of time to teach each of these skills thoroughly. It has proven to be unwise to attempt to have students incorporate more than one of these skills into the research process initially. A first step for many bibliographic instruction programs may be simply to incorporate information on library-owned software programs appropriate to library research-related tasks into classroom presentations for upperdivision and graduate students. 
Unlike the hands-on workshops, the seminars have assumed a basic level of familiarity with the use of microcomputers on the part of those attending. This format has turned out to be well suited to meeting the need simply to make patrons aware of software suitable for particular purposes and how it might best be used. A significant outcome of the seminars is that they have increased opportunities for librarians to act as consultants; as a result of the seminars librarians have often been called upon by teaching faculty seeking advice on accessing online search services and managing reprint files. In general, teaching skills and experience gained previously by librarians active in bibliographic instruction programs have been helpful and relevant to the task of developing and teaching microcomputer workshops and seminars.

There have been a number of specific benefits at UW-Parkside resulting from the new role of academic librarians as instructors and consultants in microcomputer literacy and applications. Many patrons who might otherwise never have utilized microcomputers have become enthusiastic beneficiaries of the productivity potential inherent in microcomputer applications. Faculty, in particular, have been prepared to introduce their students to discipline-specific applications of microcomputers, which otherwise might have been ignored. Further, the emerging role of librarians as technologically adept professionals with expertise in the latest technology has enhanced the image of librarians in the eyes of a number of faculty and administrators. Finally, the expertise gained by librarians in the use of microcomputer applications has paid off in gains in operational efficiency, as the li- brary staff has increasingly utilized micros for a variety of in-house applications.

Librarians have traditionally been the interface between patrons and information, possessing an understanding of the way information is organized while at the same time being able to work well with people. This fundamental role remains the same, even with the new technology, but the skills needed by librarians, researchers, and students will change. As more sources of information become available via computer, librarians must assume leadership roles in working with users to insure their ability to access, evaluate, organize, and manipulate this information.

Librarians can play a significant role in promoting general computer literacy on their campuses, and they must play a central role in promoting information literacy. The microcomputer is an important information retrieval and management tool, and librarians have an obligation to help users utilize it for research and information purposes. Further, as patrons increasingly use microcomputers to access information from remote locations, librarians' roles will be more concerned with consulting with and teaching users about the new technology than with the direct provision of information. Librarians, more than perhaps any other group on campus, are attuned to working with people to access and manage information. Teaching faculty are facing up to the necessity of integrating microcomputers into the curricula of their specific disciplines; librarians should do the same with the bibliographic instruction curriculum. The assumption of a proactive and dynamic role by librarians will help them to play central roles in the technological future of the university.

\section{REFERENCES}

1. John Berry, "Library Use of Microcomputers: Massive and Growing," Library Journal 110:48-49 (Feb. 1, 1985).

2. Microcomputers in ARL Libraries (Washington, D.C.: Association of Research Libraries, Office of Management Studies, 1984), p.6.

3. Linda J. Piele, "Summary of Survey Results," Newsletter of the ACRL Microcomputer Services in Academic Libraries Discussion Group (June 1985).

4. Howard Curtis, "The Mann Library Microcomputer Center," Small Computers in Libraries 4:8-9 
(Dec. 1984); Linda Guyotte Stewart and James Markiewicz, "Teaching Information Retrieval: Lessons from Cornell," Wilson Library Bulletin 60:32-34,79 (Mar. 1986).

5. Alan E. Guskin, Carla J. Stoffle, and Barbara E. Baruth, "Library Future Shock: The Microcomputer Revolution and the New Role of the Library," College \& Research Libraries 45:180-82 (May 1984).

6. For discussion of the concepts of computer and information literacy, see James W. Hart, "The Library's Role in Fostering Computer Literacy," in New Directions in Librarianship, no.7 (Westport, Conn.: Greenwood, 1985) p.179-90; Forest Woody Horton, Jr., "Information Literacy vs. Computer Literacy," ASIS Bulletin 10:14-16 (Apr. 1983); Pamela Englebrect and Linda Richardson, "Open Forum on Information Literacy," LIRT News 8:1-2 (Mar. 1986).

7. Richard M. Dougherty and Wendy P. Lougee, "What Will Survive?" Library Journal 110:43-4 (Feb. 1, 1985). 